\title{
KARAKTERISTIK KARKAS DAN DAGING SAPI BRAHMAN CROSS HASIL PENGGEMUKAN PADA BERBAGAI BOBOT POTONG
}

\section{Ujang Suryadi \\ INTISARI}

\begin{abstract}
Penelitian ini bertitiktolak dari usaha penggemukan sapi Indonesia yang selalu menggunakan Brahman Cross sebagai sapi bakalan. Bobot potong yang berat hasil penggemukan tidak menjamin diperolehnya karkas dan daging dengan karakteristik yang diterima pasaran, terutama dalam kaitannya dengan preferensi konsumen. Oleh karena itu dilakukan penelitian dengan tujuan mengkaji pengaruh bobot potong terhadap karakteristik karkas dan daging sapi Brahman Cross hasil penggemukan serta menentukan bobot potong sapi Brahman Cross yang optimum ditinjau dari aspek produksi. Penelitian dilaksanakan dengan metode observasi. Data dianalisis dengan metode Sidik Ragam Klasifikasi Satu Arah, dilanjutkan dengan Uji Duncan. Bobot potong yang diteliti terdiri atas 4 perlakuan yaitu : 1) $300-320 \mathrm{~kg}$, 2) $350-370 \mathrm{~kg}$, 3) $400-420$ $\mathrm{kg}, 3) \quad 450-470 \mathrm{~kg}$, masing-masing diulang 5 kali. Hasil penelitian menunjukkan bahwa karakteristik karkas yang meliputi; bobot dan persentase karkas, indeks perdagingan, area longissimus dorsi, tebal lemak punggung, dan bobot whole sale cut serta retail cut pada bobot potong $450470 \mathrm{~kg}$ sangat nyata lebih tinggi dibandingkan bobot potong $300-320 \mathrm{~kg}, 350-370 \mathrm{~kg}$, dan 400-420 kg. Sedangkan yield grade menurun dengan peningkatan bobot potong. Karakteristik daging yaitu; nilai shear force, skor warna daging, dan skor marbling meningkat dengan peningkatan bobot potong. Disimpulkan karakteristik karkas dan daging sapi Brahman Cross hasil penggemukan dipengaruhi oleh bobot potong. Bobot potong $450-470 \mathrm{~kg}$ menghasilkan karakteristik karkas dan daging yang berkualitas baik dan menguntungkan dari aspek produksi.
\end{abstract}

(Kata kunci : Karakteristik, Karkas, Daging, Brahman cross, Bobot potong).

Buletin Peternakan 27 (2) : 46 - 54, 2003

\footnotetext{
'Jurusan Peternakan Politeknik Negeri Jember.
} 


\title{
THE CHARACTERISTICS OF CARCASS AND MEAT OF BRAHMAN CROSS
}

\section{FATTENED AT SOME LEVELS OF SLAUGHTERED WEIGHT}

\begin{abstract}
The idea of this research came from the fact that cattle fattening in Indonesia used mostly Brahman Cross as feeder cattle. When slaughtered weight was abstained it did not always accompanied with carcass and meat characteristic accepted by market, specially by consumer's preference. It is therefore, this experiment was conducted to see the relationship slaughtered battered weight wit characteristic of carcass and meat of between Brahman Cross, and to see the optimal weight. The research was done by observation method. The data were analyzed using one way analysis of variance, followed with Duncan Test. Slaughtered weight were categorized as I) 300 to $320 \mathrm{~kg}$, 2) 350 to $270 \mathrm{~kg}, 3) 400$ to $420 \mathrm{~kg}$ and 4) 450 to $470 \mathrm{~kg}$ with five replication each. The results of the study indicated that carcass characteristics which included carcass weight and percentage, fleshing index, the area of longissimus dorsi, thickness of back fat, whole sale cut and retail cut were found highest on 450 to $470 \mathrm{~kg}$ slaughtered weight cattle compared to the other groups. Yield grade decreased with increasing slaughtered weight. Meat. characteristics included shear force score, meat color and marbling score increased with increasing slaughtered weight. It was concluded carcass and meat of the fattened Brahman Cross was influenced by the slaughtered weight. Slaughtered weight of 450 to $470 \mathrm{~kg}$ produced meat and carcass characteristics of good quality and benefiting from production aspect point of view.
\end{abstract}

(Key words : Characteristics, Carcass, Meat, Brahman Cross, Slaughtered weight).

\section{Pendahuluan}

Daging sapi sebagai bahan pangan produk peternakan memiliki nilai gizi relatif lengkap dan seimbang. Permintaan daging sapi dari tahun ke tahun mengalami peningkatan seiring dengan tumbuhnya "sadar gizi" dan selera konsumsi masyarakat terhadap daging sapi. Brahman Cross merupakan salah satu diantara beberapa sapi potong yang mempunyai kontribusi cukup berarti bagi pemenuhan kebutuhan daging di Indonesia, karena sapi tersebut banyak digunakan sebagai bakalan penggemukan oleh "feedlotter". Industri penggemukan sebagai pemasok daging, selalu berupaya untuk mengefisienkan produksi dengan menghasilkan karkas ideal yaitu karkas yang memiliki bobot dan persentase tinggi, nilai kualitas baik, dan benilai ekonomis.

Peningkatan laju pertambahan bobot badan harian merupakan upaya utama penggemukan untuk mencapai bobot potong tinggi dalam waktu relatif singkat. Namun demikian, bobot potong terlalu berat kurang disukai oleh jagal karena akan mengurangi pendapatan yang diperoleh dari bagian nonkarkas untuk setiap ekor sapi, di samping itu bobot potong terlalu berat tidak menjamin diperolehnya daging dengan karakteristik yang diterima di pasaran, apabila disertai dengan kandungan lemak tinggi sebab periemakan merupakan salah satu faktor penentu klasifikasi kualitas daging. Oleh karena itu, bobot potong merupakan faktor pertimbangan utama bagi kebanyakan produsen penggemukan sapi untuk memperoleh keuntungan.

Nilai ekonomis karkas sapi di pasaran ditentukan oleh karakteristik karkas yang meliputi kualitas karkas dan hasil karkas. Kualitas karkas diantaranya yaitu: ukuran karkas perdagingan tingkat kedewasaan skor marbling, dan warna daging. Sedangkan hasil karkas meliputi bobot karkas panas, persentase lemak ginjal, pelvis dan jantung, ketebalan lemak punggung dan jumlah lemak harus dibuang yang dimanifestasikan oleh yield grade. Bobot karkas dan recahan komersial 
karkas merupakan salah satu variabel penentu utama untuk menilai ekonomis karkas pada saat ini.

Karakteristik karkas meliputi kualitas karkas (carcass quality) dan hasil karkas (carcass yield). Kualitas karkas ditentukan oleh beberapa faktor yaitu: ukuran karkas. perdagingan, tingkat kedewasaan, dan skor kepualaman (Paschal et al 1995). Ukuran karkas ditentukan oleh nilai indeks perdagingan karkas. Karkas yang baik memiliki kreteria bulat sekali (very round) dengan indeks lebih dari $2,05 \mathrm{~kg} / \mathrm{cm}$ panjang karkas (Kempster el al 1982) Luas urat daging mata rusuk digunakan dalam menentukan perdagingan sebab memberikan indikasi terhadap besarnya proporsi daging yang terdapat pada karkas. Peningkatan luas urat daging mata rusuk menyebabkan peningkatan hasil recahan karkas. Luas urat daging mata rusuk minimum 2 inci $^{2}$ per 100 lbs $\left(27,56 \mathrm{~cm}^{2}\right.$ per $\left.100 \mathrm{~kg}\right)$ bobot karkas (Minish dan Fox, 1979).

Banyaknya lemak yang menutupi karkas merupakan faktor penting untuk menentukan yield grade, sebab memberikan indikasi terhadap jumlah lemak yang dibuang (Swatland, 1984; Taylor, 1994). Perlemakan yang berlebihan dalam proses penggemukan akan merugikan produsen daging, karena lebih banyak energi yang dibutuhkan per kilogram pertambahan bobot badan. Recahan karkas berkurang 2 persen dengan peningkatan 0,075 inci $(1,88 \mathrm{~mm})$ ketebalan lemak punggung. Ketebalan lemak punggung $0,2-0,3$ inci $(5-7,5$ $\mathrm{mm})$ dapat mencegah kerusakan dan perubahan warna karkas selama proses pendinginan dan prosedur penanganan lainnya (Minish dan Fox, 1979)

Kedewasaan dan kepualaman keduanya merupakan faktor yang penting untuk menentukan kualitas karkas, sebab ada hubungannya dengan penambahan umur ternak dan penurunan keempukan daging. Tingkat kedewasaan penting karena dapat digunakan sebagai indikator warna dan tekstur daging (Minish dan Fox 1979).
Daging merupakan komponen utama karkas. Daging adalah otot hewan setelah berhenti fungsi fisiologinya (Soepamo, 1994). Komponen utama daging terdiri atas jaringan (muscle tissue), jaringan lemak (adipose tissue), sejumlah jaringan ikat (comnective tissue, colagen, elastin dan reticulin), serta pembuluh darah, epithel dan saraf (Tien dan Sugiyono, 1992). Karakteristik daging ditentukan sifat fisik dan kimia, kedua sifat ini adalah faktor yang turut menentukan nilai atau mutu daging ternak. Sifat fisik daging merupakan faktor yang menentukan dalam penilaian konsumen terhadap mutu daging antara lain keempukan (tenderness). cita rasa (flawour), tekstur, aroma, warna, kegurihan, kepualaman, hilangnya air selama perebusan atau susut masak (cooking loxs), daya mengikat air oleh protein daging atau waterholding capacity (WHC) dan $\mathrm{pH}$ daging (Lawrie, 1985; Soeparno, 1994)

Pada bobot potong yang berat, ukuran tubuh juga dipertimbangkan dapat mempengaruhi proporsi bagian-bagian potongan daging Oleh karena itu Berg dan Butterfield (1976) menyatakan bahwa hubungan antara ukuran tubuh dan perdagingan sangat perlu diketahui karena ternak yang mempunyai proporsi tulang yang rendah dari keselunuhan karkas. memiliki proporsi daging yang tinggi.

Berdasarkan uraian di atas tampak kiranya bahwa bobot potong sapi yang berat tidak selalu disertai dengan perbaikan karakteristik karkas dan daging, untuk itu diperlukan adanya penelitian yang bertujuan mengkaji pengaruh bobot potong terhadap karakteristik karkas Sapi Brahman Cross hasil penggemukan. Menentukan bobot potong Sapi Brahman Cross dengan karakteristik daging yang menguntungkan ditinjau dari aspek produksi. Sehingga hasil penelitian ini diharapkan memberikan sumbangan ilmiah mengenai katerkaitan antara karakteristik karkas dan karakteristik daging sapi dengan bobot potong. Selain itu diharapkan juga dapat memberikan sumbangan pemikiran dan informasi bagi industri peternakan sapi potong dalam membuat program pengelolaan ternak 
untuk menentukan bobot potong optimum dengan hasil karkas bernilai ekonomis tinggi dalam hubungannya dengan efisiensi produksi dan efisiensi prosesing pada industri pemotongan.

\section{Materi dan Metode}

Penelitian ini menggunakan karkas Sapi Brahman cross hasil penggemukan yang diperkirakan berumur 18-30 bulan. Penentuan umur dilakukan dengan cara melihat perubahan 2 buah buah gigi seri menjadi permanen. Sapi Brahman, selama digemukan diberi ransum secara ad libirum dengan kandungan energi $10 \mathrm{Mj}$, kandungan protein minimal $12 \%$, kandungan lemak $3 \%$, dan bahan kering minimal $85 \%$ (PT. Prasanja Abadi).

Penelitian dilaksanakan dengan metode observasi melalui pengamatan langsung di feedlot dan abhaloir serta di laboratorium Data yang diperoleh dianalisis dengan metode
Sidik Ragam Klasifikasi Satu Arah, dilanjutkan dengan Uji Duncan. Bobot potong yang diteliti terdiri atas 4 perlakuan, setiap perlakuan diulang 5 kali. Bobot potong yang diteliti adalah : 1) $\left.300 \mathrm{~kg}-320 \mathrm{~kg}\left(\mathrm{BP}_{1}\right), 2\right) 350 \mathrm{~kg}-370$ $\left.\left.\mathrm{kg}\left(\mathrm{BP}_{2}\right), 3\right) 400 \mathrm{~kg}-420 \mathrm{~kg}\left(\mathrm{BP}_{3}\right), 3\right) 450 \mathrm{~kg}$ $470 \mathrm{~kg}\left(\mathrm{BP}_{4}\right)$. Peubah yang diamati pada penelitian yaitu : 1) bobot karkas, 2) persentase karkas, 3) indeks perdagingan (Fleshing Indeks), 4) area longisimus dorsi, 5) tebal lemak punggung, 6) bobot whole sale cut, 7) bobot retail cut, 8) yield grade, 9) keempukan, 10) marbling, dan 11) warna daging.

\section{Hasil dan Pembahasan}

Hasil penelitian karakateristik karkas dan daging Sapi Brahman Cross Hasil Penggemukan pada berbagai bobot potong tercantum pada Tabel 1.

Tabel I. Karakateristik Karkas dan Daging Sapi Brahman (ross Hasil Penggemukan pada Berbagai Bobot Potong (/he characteristics of carcass and meat of Brahman Cross fattened at some levels of slaughter's weight)

\begin{tabular}{|c|c|c|c|c|}
\hline \multirow[b]{2}{*}{ Parameter (Parameter) } & \multicolumn{4}{|c|}{ Bobot potong (Slaughtered weight) (Kg) } \\
\hline & $\begin{array}{c}300-320 \\
\left(\mathrm{BP}_{1}\right)\end{array}$ & $\begin{array}{c}350-370 \\
\left(\mathrm{BP}_{2}\right)\end{array}$ & $\begin{array}{c}400-420 \\
\left(\mathrm{BP}_{3}\right)\end{array}$ & $\begin{array}{c}450-470 \\
\left(\mathrm{BP}_{4}\right)\end{array}$ \\
\hline Bobot karkas (carcass weight). (kg) & $160,1^{\mathrm{d}}$ & $186,3^{\mathrm{c}}$ & $220,5^{b}$ & $250,6^{2}$ \\
\hline Persentase karkas (carcass percentage). (\%) & $50,31^{\mathrm{t}}$ & $51,10^{\mathrm{b}}$ & $53,04^{a}$ & $53,48^{a}$ \\
\hline Indeks perdagingan (/Fshing linkeks) & 1,36 & 1,57 & 1,84 & 2,08 \\
\hline Area longisimus dorsi, $\left(\mathrm{cm}^{2}\right)$ & $55,3^{c}$ & $63,0^{h}$ & $78.0^{2}$ & $80,1^{11}$ \\
\hline Tebal lemak punggung (hackfar). (mm) & $4.6^{4}$ & $5,6^{\mathrm{b}}$ & $8,8^{a}$ & $9.6^{2}$ \\
\hline Potongan utama karkas (whole sale cut), (kg) & $101,05^{\mathrm{d}}$ & $106.89^{c}$ & $110,25^{b}$ & $118,13^{2}$ \\
\hline Recahan karkas (retail cmr). (kg) & $14,53^{d}$ & $15,47^{\circ}$ & $17,03^{\mathrm{b}}$ & $18,11^{\text {in }}$ \\
\hline Yield Grade & 2.07 & 1.91 & 1,71 & 1,93 \\
\hline Keempukan (shear force $\mathrm{s}),\left(\mathrm{kg} / \mathrm{cm}^{2}\right)$ & $2,50^{b}$ & $2,70^{h}$ & $2,76^{\mathrm{b}}$ & $3,38^{\mathrm{a}}$ \\
\hline Marbling & 1.4 & 1,6 & 2,4 & 2.6 \\
\hline Warna daging (meat (olor) & 3.6 & 3,8 & 4,4 & 5,2 \\
\hline
\end{tabular}

Superskrip yang berbeda pada kolom yang sama menunjukkan perbedaan $(P<0,01)($ Means within the same column with different superscript are different, $P(0.01)$

Parameter no. 3, 8, 10, dan 11 tidak diuji Duncan (No. 3,8,10 and 11 parameters were not analyzed by Duncan test) 
Berdasarkan hasil Uji Duncan (Tabel 1), nampak bahwa rataan bobot karkas sapi Brahman Cross dari bobot potong $450-470 \mathrm{~kg}$ $(250,6 \mathrm{~kg})$ sangat nyata $(\mathrm{P}<0,01)$ lebih berat dibandingkan rataan bobot karkas dari bobot potong $300-320 \mathrm{~kg}(160,1 \mathrm{~kg}), 350-370 \mathrm{~kg}$ $(186,3 \mathrm{~kg})$, dan $400-420 \mathrm{~kg}(220,5 \mathrm{~kg})$. Hal ini disebabkan pada bobot potong yang lebih berat mempunyai proporsi komponen karkas yang lebih berat pula. Di samping itu karena bobot non-karkas relatif sama untuk setiap bobot potong. Selama pertumbuhan postnatal pola pertumbuhan organ seperti hati, ginjal, dan saluran pencernaan kadar laju kenaikan beratnya relatif lambat dibandingkan kenaikan bobot badan (Soeparno, 1994). Berg dan Butterfield (1976), menyatakan bahwa bobot total relatif saluran pencernaan terhadap bobot potong menurun pada saat mencapai kedewasaan tubuh, walaupun kadar laju pertumbuhan relatif komponen non-karkas hampir sama dengan kadar laju pertumbuhan tubuh, misalnya abomasum dan usus besar mencapai kedewasaan hampir bersamaan dengan tubuh

Persentase karkas yang diperoleh dari Brahman (ross $450-470 \mathrm{~kg}$ ( 53,48 persen) sangat nyata $(\mathrm{P}<0,01)$ lebih tinggi dibandingkan persentase karkas dari bobot potong $300-320 \mathrm{~kg}$ (50,31 persen), $350-370 \mathrm{~kg}$ (51,10 persen), namun tidak nyata dibanding persentase karkas pada Sapi Brahman Cross dengan bobot potong $400-420 \mathrm{~kg} \quad(53,04$ persen). Hal ini diduga pada bobot potong $450-470 \mathrm{~kg}$. peningkatan bobot badan salah satunya sebagai akibat deposisi omental fat dan mesentric fat yang banyak dibandingkan pada bobot potong $400-420 \mathrm{~kg}$. Mangoub et al. (1995), mengemukakan bahwa kadar laju pertumbuhan organ dalam selama penggemukan adalah lambat, proporsi organ dalam akan menurun mengingat cepatnya laju pertumbuhan omental fat dan mesentric fat dengan meningkatkan bobot potong Omental fat dan mesentric fat merupakan lemak yang ikut terbuang bersama saluran pencernaan.

Pada Tabel 1, nampak bahwa bobot karkas dari bobot potong $450-470 \mathrm{~kg}$ berbeda sangat nyata $(\mathbf{P}<0,01)$ lebih tinggi dibandingkan bobot karkas dari bobot potong $400-420 \mathrm{~kg}$. Namun berdasarkan perhitungan persentase, persentase karkas dari bobot potong $450-470 \mathrm{~kg}$ tidak lebih tinggi dibandingkan persentase karkas dari bobot potong $400-420 \mathrm{~kg}$. Hal ini disebabkan perbedaan dasar perhitungan. Bobot karkas dihitung langsung dari hasil penimbangan, sedangkan persentase karkas dihitung dari hasil perbandingan bobot karkas dengan bobot potong. Sementara bobot potong, beratnya dipengaruhi komponen non-karkas.

Rataan indeks perdagingan pada Tabel 1. menunjukkan adanya peningkatan seiring dengan meningkatnya bobot potong. Rataan indeks perdagingan meningkat dari 1,36 pada sapi Brahman Cross dengan bobot potong 300-320 kg menjadi 2,08 pada bobot potong $450-470 \mathrm{~kg}$. Indeks perdagingan 2,08 menunjukkan skor konformasi tubuh sapi bulat sekali (very round) (Kempster et al., 1982). Hal ini disebabkan pada bobot potong yang lebih berat mempunyai proporsi komponen karkas yang lebih berat pula, hal ini nampak pada bentuk tubuh yang lebih kompak dan padat serta besar. Ternak dewasa yang mempunyai ukuran tubuh besar cenderung memiliki proporsi daging banyak (Amer et al. 1992). Ketebalan daging terhadap komposisi karkas lebih nyata dalam kelompok ternak yang mempunyai ukuran tubuh besar (Tatum et al. 1986)

Peningkatan indeks perdagingan seiring dengan meningkatnya bobot potong. disebabkan oleh bobot karkas yang diperoleh dari bobot potong $450-470 \mathrm{~kg}$ sangat nyata $(\mathrm{P}<0,01)$ lebih berat dibandingkan bobot potong $300-320 \mathrm{~kg}, 350-370 \mathrm{~kg}$, dan $400-420$ kg. Sementara itu panjang karkas untuk setiap bobot potong tidak menunjukkan penambahan panjang yang linier dengan peningkatan bobot potong. Tulang sebagai komponen utama karkas memiliki laju pertumbuhan relatif lambat dibandingkan pertumbuhan otot dan lemak, hal ini ditunjukkan oleh koefisien pertumbuhan tulang yang lebih rendah yaitu 0,70 , sedangkan koefisien pertumbuhan otot 
0,93, dan lemak 1,89 (Tulloh, 1978). Disamping itu tulang merupakan komponen karkas yang tumbuh dan berkembang paling dini, kemudian disusul oleh otot dan terakhir adalah jaringan lemak (Soeparno, 1994).

Rataan area longissimus dorsi menunjukkan adanya peningkatan seiring dengan meningkatnya bobot potong. Rataan area longissimus dorsi meningkat $7,7 \mathrm{~cm}^{2}$ dari bobot potong $300-320 \mathrm{~kg}\left(55,3 \mathrm{~cm}^{2}\right)$ ke bobot potong $350-370 \mathrm{~kg}\left(63,0 \mathrm{~cm}^{2}\right), 5,0 \mathrm{~cm}^{2}$ dari bobot potong $350-370 \mathrm{~kg}\left(63,0 \mathrm{~cm}^{2}\right)$ ke bobot potong $400-420 \mathrm{~kg}\left(78,0 \mathrm{~cm}^{2}\right)$, dan $2,1 \mathrm{~cm}^{2}$ dari bobot potong $400-420 \mathrm{~kg}\left(78,0 \mathrm{~cm}^{2}\right) \mathrm{ke}$ bobot potong $450-470 \mathrm{~kg}\left(80,1 \mathrm{~cm}^{2}\right)$. Namun demikian, bila ditinjau dari laju pertumbuhannya mengalami penurunan. Hal ini disebabkan karena semakin dewasa tubuh laju pertumbuhan komponen tubuh akan melambat

Area longissimus dorsi dari masingmasing bobot potong yang diteliti menunjukkan hasil di atas luas minimum yaitu $69,06 \mathrm{~cm}^{2}$ per $100 \mathrm{~kg}$ bobot karkas pada bobot potong $450-470 \mathrm{~kg} .60,76 \mathrm{~cm}^{2}$ per 100 $\mathrm{kg}$ bobot karkas pada bobot potong $400-420$ kg. $51.34 \mathrm{~cm}^{2}$ per $100 \mathrm{~kg}$ bobot karkas pada bobot potong $350-370 \mathrm{~kg}$, dan $44,12 \mathrm{~cm}^{2}$ per $100 \mathrm{~kg}$ bobot karkas pada bobot potong 300 $320 \mathrm{~kg}$. Area longissimus dorsi minimum yaitu $27,56 \mathrm{~cm}^{2}$ per $100 \mathrm{~kg}\left(2\right.$ inci $^{2}$ per 100 lbs) (Minish dan Fox, 1979).

Perluasan area longissimus dorsi pada bobot potong sapi Brahman Cross 450-470 kg disebabkan oleh meningkatnya deposisi lemak di antara serat-serat otot (intramuskuler) di samping bertambahnya jumlah dan besar ukuran otot longissimus dorsi itu sendiri. Peningkatan bobot potong menyebabkan peningkatan luas longissimus dorsi dan ketebalan lemak punggung. Korelasi parsial antara bobot karkas dengan longissimus dorsi yaitu 0,5 dengan tebal lemak punggung 0,9 dan dengan lemak ginjal 0,95 (Prestone dan Willis, 1982). Semakin tinggi bobot hidup, makin luas otot longissimus dorsi. Luas area longissimus dorsi berkorelasi positif dengan bobot karkas ternak (Course et al. 1985).
Lemak punggung pada bobot potong 450-470 kg yang lebih tebal, diduga disebabkan sapi-sapi pada kelompok bobot potong tersebut telah memasuki fase penggemukan dan otot telah mencapai pertumbuhan maksimum. Selama fase penggemukan, persentase lemak dalam jaringan akan bertambah. Peningkatan kadar lemak berhubungan linier dengan pertambahan umur dan bobot potong, tetapi peningkatannya tidak tetap, seperti pengaruh pakan, umur, dan bobot potong terhadap kualitas fisik daging (Soeparno dan Davies, 1987).

Ketebalan lemak punggung $9,6 \mathrm{~mm}$ pada bobot potong $450-470 \mathrm{~kg}$, bila dibandingkan tolak ukur ketebalan lemak punggung yang lebih mendekati keadaan kepualaman yang disukai konsumen, yaitu kurang dari $5,6 \mathrm{~mm}$ per $100 \mathrm{~kg}$ bobot karkas (Minish dan Fox,1979), maka ketebalan lemak punggung pada kelompok bobot potong 450 $470 \mathrm{~kg}$ termasuk ke dalam kriteria disukai konsumen

Peningkatan bobot whole sale $\mathrm{cu}$ dan retail $\mathrm{cut}$ seiring dengan peningkatan bobot potong disebabkan oleh perbedąan bobot karkas di antara kelompok bobot potong sapi yang diteliti. Hasil $\mathrm{Uji}_{\mathrm{ji}}$ larak Berganda Duncan (Tabel 1), nampak bahwa rataan bobot whole sale cut dan retail cut dari bobot potong $450-470 \mathrm{~kg}$ sangat nyata $(P<0.01)$ lebih berat dibanding rataan bobot whole sale cut dan retail cut dari bobot potong dibawahnya. Berg dan Butterfield (1976), mengemukakan bahwa karkas sapi yang lebih berat akan mempunyai beberapa bagian karkas lebih berat. Variasi potongan komersial dapat pula disebabkan oleh variasi bobot komponen penyusun karkas termasuk ketebalan lemak punggung. May $e t$ al. (1992), mencatat ukuran tubuh dan tebal lemak pada potongan rusuk ke- 12 menentukan persentase dari bagian-bagian potongan subprimal karkas, persentase potongan primal dan subprimal karkas banyak ditentukan oleh tebal lemak punggung, sedangkan ukuran tubuh pengaruhnya lebih kecil terhadap potongan karkas. 
Rataan yield grade menunjukkan adanya variasi di antara kelompok bobot potong. Rataan yield grade pada bobot potong $450-470 \mathrm{~kg}(1,93)$, bobot potong $400-420 \mathrm{~kg}$ $(1,73)$, dan $320-350 \mathrm{~kg}(1,91)$, masing-masing memiliki nilai akhir yzeld grade sama yaitu 1 . $\mathrm{Hal}$ ini berarti kelompok bobot potong tersebut memiliki proporsi daging tenutama daging round, loin, rib, dan chuck di atas 52,4 persen atau dapat menghasilkan sekitar 82 persen retail cut Rataan yield grade pada bobot potong $300-320 \mathrm{~kg}(2,05)$ dengan nilai akhir yiled grade 2 , berarti porsi daging round, loin, rib, dan chuck berkisar $50,1-52,3$ persen atau diperkirakan menghasilkan retail cut sekitar 77,4 persen

Variasi rataan yield grade dari setiap bobot potong disebabkan karena ketebalan lemak punggung dari setiap kelompok bobot potong berbeda Ketebalan lemak bobot potong sapi Brahman (ross 450-470 kg sangat nyata ( $\mathrm{P}<0,01)$ lebih tebal dibandingkan rataan tebal lemak punggung dari bobot potong 300 $320 \mathrm{~kg}$, dan $350-370 \mathrm{~kg}$. Lemak mempunyai pengaruh besar terhadap proporsi jaringan otot dalam karkas sehingga dapat mempengaruhi nilai karkas tersebut (Berg dan Butterfield, 1976). Di samping ketebalan lemak punggung, perbedaan yield grade dapat disebabkan oleh perbedaan luas otot /ongissimus dorsi.

Nilai shear force kelompok bobot potong $450-470 \mathrm{~kg}$ nyata lebih tinggi dibandingkan bobot potong dibawahnya, diduga disebabkan oleh perbedaan pertumbuhan dan perkembangan unit struktural jaringan otot. Unit struktural jaringan otot dari bobot potong yang berat akan memiliki jaringan ikat dan berkas otot banyak dan besar akibat pertumbuhan dan perkembangan otot yang cepat, sehingga kandungan kolagen dan ikat silangnya di dalam sel otot (serabut otot) juga mengalami perubahan yang sama. Kolagen dapat mempengaruhi keempukan daging, karena kolagen terdapat dalam jumlah yang relatif banyak di dalam otot dan mengalami perubahan-perubahan molekuler selama perkembangan kedewasaan ternak (Forrest et al. 1975, dan Taylor, 1994).
Keempukan daging menurun dengan bertambahnya umur dan meningkatnya bobot potong, hal ini disebabkan oleh perbedaan jumlah jaringan ikat serta ukuran serat dan serabut otot (Lawrie, 1985). Disamping itu, karkas yang memiliki kandungan lemak tebal mempunyai penurunan temperatur postmortem yang lebih lambat daripada karkas dengan lemak tipis Penurunan temperatur yang lambat menyebabkan cepatnya proses glikolisis, yang diikuti oleh penurunan $\mathrm{pH}$ yang cepat sehingga $\mathrm{pH}$ ultimatnya rendah (Mitsumoto et al 1992). Penelitian terdahulu menunjukkan bahwa $\mathrm{pH}$ ultimat (akhir) otot behubungan dengan keempukan daging (Jones dan Tatum, 1994). Tingginya rataan nilai shear force daging dari bobot potong sapi Brahman Cross $450-470 \mathrm{~kg}$ yaitu $3.38 \mathrm{~kg} / \mathrm{cm}^{2}$. belum mengindikasikan keempukan daging yang tidak disukai oleh konsumen, sebab hasil penelitian lebih dari 90 persen produsen steak menggunakan daging dari karkas yang memiliki nilai shear force di bawah $3.9 \mathrm{~kg} / \mathrm{cm}^{2}$ (Minish dan Fox, 1976)

Skor warna daging mengalami peningkatan ke arah merah gelap sesuai dengan peningkatan bobot potong $\mathrm{Hal}$ ini karena unit struktural jaringan otot dari bobot potong yang berat memiliki berkas otot yang banyak dan besar, sehingga mioglobin yang terkandung di dalam sel otot (serabut otot) juga mengalami peningkatan konsentrasinya. Mioglobin merupakan pigmen berwarna merah keunguan yang dapat mengalami perubahan akibat reaksi kimia Oksigenasi mioglobin akan membentuk oksimioglobin yang berwarna merah cerah (Tien dan Sugiyono, 1992) Warna daging yang lebih disukai konsumen berada dalam kisaran skor 4 sampai 6 , tetapi skor 4 yang mendekati selera (Santosa, 1996). Berdasarkan rataan skor warna daging, daging dari bobot potong 450$470 \mathrm{~kg}$ masih termasuk ke dalam warna daging yang disukai konsumen.

Skor kepualaman menunjukkan kecenderungan mengalami peningkatan dengan meningkatnya bobot potong. Kepualaman bobot potong $450-470 \mathrm{~kg}$, bila dibandingkan 
standardisasi dari USDA termasuk kisaran slight atau sedikit sekali. Karkas dengan skor kepualaman slight banyak digunakan oleh industri steak sebagai bahan baku produknya (Jones dan Tatum, 1994). Dengan demikian skor kepualaman pada bobot potong 450-470 $\mathrm{kg}$ termasuk disukai konsumen. Nilai terjadi karena pertumbuhan otot telah menuju ke arah pertumbuhan maksimum dan sapi memasuki periode penggemukan, sehingga deposisi lemak di samping pada punggung juga terjadi di antara serabut otot. Leat (1976) menyatakan bahwa setelah otot mencapai pertumbuhan maksimum, pertumbuhan otot terjadi terutama karena deposisi lemak intramuskuler

\section{Kesimpulan}

Karakteristik karkas dan daging sapi Brahman Cross hasil peggemukaan dipenganuhi oleh bobot potong Peningkatan bobot potong diikuti oleh peningkatan bobot dan persentase karkas, indeks perdagingan, perluasan area longisimus dorss, penambahan ketebalan lemak punggung, peningkatan bobot whole sale cul dan retail cm, peningkatan skor marbling. dan warna daging tetapi cenderung menurunkan keempukan daging. Namun demikian, peningkatan bobot potong tidak disertai dengan peningkatan yie/d grade. Bobot potong 400 sampai $470 \mathrm{~kg}$ menyebabkan diperolebnya karakteristik karkas dan daging yang lebih berkualitas dan menguntungkan dari aspek produksi.

\section{Daftar Pustaka}

Amer, P. R., R. A. Kemp and C. Smith. 1992 Genetik Differences among the Predominant Beef Cattle Breeders in Canada J. Anin. Sci 72 759-771

AMLC. 1993. Handbook of Australian Meat. $5^{\text {th }}$ Ed Australian Meat and Livestock Corporation.

Berg. R. T. and R. M. Butterfield 1976. New Concepts of Cattle Growth. Sidney University Press
Crouse, J. D. H R. Cross and S. C Seideman 1985. Effect of sex Condition, Genotype, Diet and Carcass Electrical Stimulation on Collagen Content and Palatability of Two Bovin Muscles. J. Anim. Sci. $60: 1228$ 1234.

Forrest, J. C, E. D Aberle, H. B Hedrick, M O Judge dan R. A. Merkel. 1975 Principles of Meat Science W.H Freeman and Company. San Fransisco

Jones, B. K dan J D. Tatum. 1994 Predictors of Beef Tenderness Among Carcass Produced Under Commercial Condition J Anim Sci. 72: 1492 1501

Kempster, T., C, Alastair and H. Geof. 1982 Carcass Evaluation in Livestock Breeding. Production and Marketing $1^{\text {st }}$ Ed. Granada Publishing Ltd. USA.

Lawrie. R. A. 1988 Meat Science $4^{\text {th }} \mathrm{Ed}$ Pergamon Press, Oxford-New YorkSidney-Paris-Frankfurt

Leat, W M. P 1976. Growth and Productivity Dalam Meat Animal Plenum Press New York and London. Mangoub, O. E H Olvey dan D C. Jeffrey 1995. Body Weight Growth and Carcass Composition. Aust. J Anim. Sci. 86 611-616

May, S G. W. L Mies, J. W Edwards, F, L Williams, J. W. Wise, J. B Morgan, J. W. Savel and H. R. Cross 1992 Beef Carcass Composition of Slauhgter Cattle Differing in Frime Size, Muscle Score and External Fatness. J Anim. Sci. $70: 2431-2445$

Minish, G. L. and D G Fox. 1979. Beef Production dan Management. Reston Publishing Co. Inc A Prentice Hall Co., Reston Virginia

Mitsumoto, M T., Mitsuhashi dan S. Ozawa. 1992. Influence of Slaughter Weight, Sire, Concentrate Feeding and Muscle on Physical and Chemical Characteristics in Japanese Black Beef Aust. J. Anim Sci. 5: 629-634. 
Paschal, J. C., J. O Sanders, J. L, Kerr, Lunt, dan A. D. Herring 1985. Postweaning and Feedlot Growth and Carcass Characteristics of Angus, Gray Brahman, Gir-, Indu - Brazil, Nellore, and Red Brahman - Sired $F_{1}$ Calves J Anim. Sci. 73: 373-380

Preston, T. R and M. B. Willis. 1982 Intensive Beef Production $2^{\text {th }}$ Ed. Pergamon Press. London

Santosa U. 1996. Efek Jerami Padi yang difermentasikan oleh Jannur Tiram Putih (Pleurotus ostreatus) terhadap Penggemukan Sapi Jantan Peranakan Ongole. Disertasi Universitas Padjadjaran. Bandung

Soepamo and H. L. Davies 1987 Studies on the Growth and Carcass Composition in Daldale Wether Lambs I The effects of Dietary Energy Concentration and Pasture Spesies Aust J Agric Res 38:403-415

Soeparno. 1994 Ilmu dan Teknologi Daging. Cetakan kedua Gadjah Mada University Press Yogyakana

Swatland, H J 1984 Structure and Development of Meat Animals
Prentice Hall, Inc. Englewood Cliffs. New Jersey.

Tatum, J. D., H. G. Dolezal, F. L. Williams, $\mathrm{Jr}$, R A Bowling, and R. E Taylor. 1986. Effect of Feeder Cattle Frame Size and Muscle Thickness on Subsequent Growth and Carcass Development. II. Absolute Growth and Associated Changes in Carcass Composition. J. Anim. Sci. 62: 121-131.

Taylor, R. E. 1994 Beef Production and Management Decision. $\quad 2^{\text {th }}$ Ed. Mac Millan Publishing Company. USA

Tien R. M. dan Sugiyono. 1992 llmu Pengetahuan Bahan Pangan Departemen Pendidikan dan Kebudayaan, Direktorat Jenderal Pendidikan Tinggi. Pusat Antar Universitas Pangan dan Gizi Institut Pertanian Bogor.

Tulloh, N. M. 1978. Growth, Development. body composition, breeding and management. Dalam: A Course Manual in R.G. Dumsday, J. E. Frisch. R.A. Swan and N.M Tulloh (eds) Australian Vice-Chanacellor Committee Academy Press Pty Ltd Brisbane 